\title{
Bimbingan Awal Kewirausahaan pada Anak Usia Dini
}

\author{
Nurhafizah Nurhafizah \\ Universitas Negeri Padang \\ ఏ e-mail: nurhafizah.is.87@gmail.com
}

\begin{abstract}
Entrepreneur education should be started in early-childhood start from introduction stages then be an entrepreneur agent. It is taught to children to be mentally an entrepreneur. Due to this activity which is design to support their business. The students began to comprehend themselves, control their emotion and stress, time management, flexible communication, and decision maker. Developing student's entrepreneur mentality increases the students' characteristic and behavior, responsibility towards an entrepreneur theoretical and practically, which is taken the long term period process.
\end{abstract}

Keywords: Guidance; enterpreneur; early childhood

Copyright (C) 2018 IICET (Indonesia) - All Rights Reserved

Indonesian Institute for Counseling, Education and Therapy (IICET)

\section{PENDAHULUAN}

Peranan kewirausahaan atau enterpreuner pada sebuah negara berkembang tidak dapat diabaikan terutama dalam melaksanakan pembangunan. Mereka dapat berkreasi serta melakukan inovasi secara optimal dengan mewujudkan gagasan-gagasan baru menjadi kegiatan yang nyata dalam setiap usahanya sehingga bangsa tersebut akan berkembang lebih cepat.

Menurut Ciputra dalam bukunya Quantum Leap, pengangguran di Indonesia setiap tahun semakin bertambah kurang lebih $20 \%$ dari jumlah penduduk Indonesia, bahkan terbesar adalah dari kalangan lulusan pendidikan, baik pendidikan tinggi maupun menengah atas. Karena lembaga pendidikan kurang fokus pada pembentukan entrepreneurship. Masyarakatpun lebih senang bila putra putrinya menjadi pegawai dibanding dengan jadi pengusaha. Maka dari itu Indonesia perlu bangkit dengan mendorong para anak muda menjadi Pengusaha atau Entrepreneur, sehingga dengan banyaknya entrepreneur roda ekonomi semakin berputar, pengangguran semakin sedikit karena tersedianya lapangan pekerjaan, kemiskinan semakin berkurang karena lapangan pekerjaan tersedia lebih banyak sehingga masyarakat miskin mendapat tambahan penghasilan, hal ini tentu saja dapat mengurangi terjadinya stres (Zola, N., Fadli, R. P., \& Ifdil, I., 2018; Alizamar, A., Ifdil, I., Fadli, R. P., Erwinda, L., Zola, N., Churnia, E., ... \& Rangka, I. B. (2018) di kalangan masyarakat yang disebabkan oleh kemiskinan dan pengangguran. 
Menurut berita Indolife 11 Maret 2012 yang tidak menyebutkan sumbernya, dinyatakan bahwa hingga akhir tahun 2011 jumlah pengusaha di Indonesia sudah mencapai 1,56\% dari jumlah penduduk Indonesia. idealnya untuk mampu memutar roda ekonomi dan penggerak pembangunan dibutuhkan $2 \%$ dari jumlah penduduk. Dibandingkan dengan Singapura tahun 2005 sudah 7,2\% entrepreneurnya, Amerika tahun 2007 entrepreneurnya berjumlah 11,5\% dari jumlah penduduk, maka Indonesia masih harus berjuang keras membangun kerajaan-kerajaan bisnis yang dapat meningkatkan jumlah Entrepreneur di Indonesia, yakni Keluarga, Masyarakat dan Lembaga pendidikan.

Keluarga, masyarakat dan lembaga pendidikan adalah elemen penting yang berpengaruh membimbing dan membentuk karakter entrepreneur. Karakter seorang anak terbentuk melalui apa yang yang didengarkan, apa yang dilihat dan apa yang dirasakan. Pendengaran dan penglihatan adalah pintu masuk pembelajaran sebelum masuk menempa hati nuraninya. Melalui seluruh indra yang manusia miliki inilah, akan muncul pembelajaran yang kuat terkait dengan apa-apa yang diterima oleh indra (PFIPUN, 2017). Bila anak terbiasa dan percaya diri (Fitri, E., Zola, N., \& Ifdil, I., 2018) dengan dunia wirausaha sejak kecil, maka karakter (Nurhafizah, 2010; Nurhafizah, 2011) inilah yang akan muncul kelak ketika anak dewasa.

Menurut Scharg et. al. (1987) wirausahawan merupakan hasil belajar. Meskipun jiwa wirausahawan mungkin juga diperoleh sejak lahir (bakat), namun jika tidak diasah melalui bimbingan dan motivasi dalam proses pembelajaran (Desyafmi, H., Firman, F., \& Ifdil, I., 2016), sulit dapat diwujudkan. Untuk mempertajam minat dan kemampuan wirausahawan, perlu ditumbuh-kembangkan melalui proses pembelajaran. Di sinilah letak dan pentingnya pendidikan wirausahawan dalam pendidikan.

Berwirausaha bukan hanya dunianya orang dewasa, tetapi juga bisa menjadi bagian dari dunianya anak-anak (Kosn, N. N. A. M., 2016). Bedanya, berwirausaha pada anak-anak tidak bisa dijalankan sendirian, namun membutuhkan bimbingan dan dukungan dari orang dewasa, orangtua maupun guru. Anak-anak yang mengenal dunia wirausaha sejak dini, akan mendapati manfaat untuk bekal masa depan kelak. Pada tahapan usia dini, anak-anak yang belajar menumbuhkan pembelajaran wirausaha akan tumbuh menjadi pribadi yang kreatif. Kreativitas yang terlatih sejak dini (Nurhafizah N., 2015), termasuk melalui berbagai kegiatan kewirausahaan, menjadi modal utama produktivitas dan kemandirian anak ketika dewasa.

Menurut psikolog anak, Dr. Seto Mulyadi (dalam Femina, No. 25/XXXVI.2008) bila ada seorang anak yang memiliki inisiatif untuk belajar berbisnis di usia dini, orangtua dan pendidik perlu memberi apresiasi gagasan ini. Inisiatif ini menunjukkan bahwa anak sudah mulai memiliki kecerdasan finansial. Kecerdasan finansial adalah kecerdasan untuk mengelola uang. Menambah pengahasilan dengan usaha seperti ini, bukanlah hal yang negatif. Justru hal ini disarankan untuk dikenalkan kepada anak sejak dini. Membimbing anak soal menabung dan menambah pengahasilan merupakan suatu cara yang efektif untuk menumbuhkan jiwa kewirausahaan sejak dini.

Pembelajaran kewirausahaan pada diri anak tidak serta merta ada, tapi memerlukan latihan bertahap. Bisa dimulai dari hal-hal kecil dalam aktivitas keseharian anak. Misalnya, membereskan mainan selesai bermain, rajin sikat gigi sebelum tidur dan membereskan tempat tidur. Ini merupakan latihan berdisiplin (Reski, N., Taufik, T., \& Ifdil, I., 2017), bertanggung jawab dan awal pengajaran tentang kepemilikan, Nurhafizah (2014). Latihan selanjutnya, mengajarkan anak untuk mampu mengelola uang dengan baik. Latihan yang perlu diajarkan bukan hanya cara membelanjakan, tapi juga menabung dan mencari uang.

Kegiatan anak di PAUD bersama guru dan teman sebayanya dapat dimaksimalkan dalam menanamkan pola pikir untuk menjadi seorang wirausaha (entrepreneur). Hal-hal yang dapat guru lakukan antara lain memberikan fasilitas, metode mengajar yang kreatif, mengaitkan apa yang diajarkan dengan berpikir layaknya seorang wirausaha. Kelak ketika dewasa nanti anak akan terbiasa dengan kegiatan kewirausahaan dan yang terpenting lagi anak tidak akan takut mengambil resiko. Kegiatan sekolah yang berkaitan dengan kewirausahaan merupakan penyeimbang bagi anak untuk menerapkan apa yang anak peroleh dari pelajaran yang diajarkan oleh guru misalnya ketika ada tema tanaman guru bisa mengajarkan cara menanam tanaman merawatnya sampai bagaimana memanfaatkan tanaman. 
Hal lain yang juga penting adalah dukungan dari orangtua kepada anak. Dukungan tidak hanya dapat berupa finansial tapi juga motivasi agar anak mau berpikir kritis untuk mengeluarkan ide. Bentuk motivasi itu antara lain bisa berwujud ucapan selamat ketika tanaman yang dipelihara anak dapat tumbuh dan anak dapat memetik hasilnya atau dorongan semangat untuk pantang menyerah. Pengakuan dan dukungan dari orang tua akan menentukan perkembangan minat dan percaya diri anak, Nurhafizah (2012). Sekolah sebagai wadah bagi anak mendapatkan ilmu dan menerapkan ilmunya untuk mengembangkan pembelajaran kewirausahaan anak, Sekolah dan orangtua merupakan kunci sukses dari program kewirausahaan pada anak usia dini.

Pembelajaran kewirausahaan perlu ditumbuhkan sejak dini bukan hanya dalam tataran pembentukan kognitif dengan memberitahu anak tentang defenisi kewirausahaan, manfaatnya dan caranya. Tetapi kewirausahaan dapat diintegrasikan dalam tema pembelajaran melalui kurikulum tersembunyi hal ini dapat dilakukan oleh guru secara kreatif pada saat pemberian materi (Primitia Yogi, 2011).

\section{PEMBAHASAN}

\section{Mengembangkan Kewirausahawan pada Anak Sejak Usia Dini}

Pengembangan karakter wirausaha dipengaruhi oleh nilai-nilai. Nilai merupakan kekuatan penggerak perubahan. Kemampuan membentuk diri dan mengaktualisasikan nilai-nilai etis merupakan ciri hakiki manusia, sehingga mampu menjadi agen perubahan. Dalam pembiasaan pembentukan perilaku misalnya pengembangan karakter kewirausahaan, peran orangtua amatlah penting. Karena orangtua adalah pendidik pertama dan utama bagi anak. Sehingga orangtualah yang bertanggungjawab menanamkan nilai-nilai tersebut yang dapat dilakukan dengan memberi contoh keteladanan dan pembiasaan dalam kehidupan sehari-hari (Nurhafizah, 2011).

Adapun prinsip pembelajaran yang digunakan dalam pengembangan pembelajaran kewirausahaan mengusahakan agar anak mengenal dan menerima nilai-nilai kewirausahaan sebagai milik anak dan bertanggung jawab atas keputusan yang diambilnya melalui tahapan mengenal pilihan, menilai pilihan, menentukan pendirian dan selanjutnya menjadikan suatu nilai sesuai dengan keyakinan diri.

Menurut Djatmiko (1998) pendidikan kewirausahaan perlu dikembangkan karena : Untuk mengembangkan, memupuk dan membina bibit atau bakat pengusaha sehingga bibit tersebut lebih berbobot dan selalu mengikuti perkembangan ilmu pengetahuan yang mutakhir. Memberikan kesempatan kepada setiap manusia supaya sedapat mungkin dan menumbuhkan kepribadian wirausaha.

Pendidikan kewirausahaan menjadi manusia berwatak dan unggul, memberikan kemampuan untuk membersihkan sikap mental negatif meningkatkan daya saing dan daya juang, Menumbuhkan cara berfikir yang rasional dan produktif. Selain itu ada faktor-faktor yang mempengaruhi wirausaha seperti: 1) Kemauan, Kemauan adalah suatu kegiatan yang menyebabkan seseorang mampu untuk melakukan tindakan dalam mencapai tujuan tertentu. 2) Ketertarikan, Ketertarikan adalah perasaan senang, terpikat, menaruh minat kepada sesuatu. Saat ada ketertarikan dari diri seseorang maka ada daya juang untuk meraih yang ingin dicapai. 3) Keluarga, Berkaitan dengan lingkungan keluarga, maka peran keluarga sangat penting dalam menumbuhkan minat anak.

Keluarga yang memainkan peranan penting dalam menghasilkan keputusan untuk memulai usaha sendiri. Menumbuhkan pembelajaran wirausaha akan lebih efektif apabila ditanamkan sejak usia dini, misalnya di China, mereka sudah mendidik anak-anaknya sejak usia kanak-kanak untuk menjadi wirausaha yang memiliki mental yang baik, cerdas dan kreatif, rajin bangun pagi, memiliki semangat, pandai menguasai masalah, memiliki pembelajaran pantang mundur dan percaya diri. Tanggungjawab, kreativitas dan mampu mengambil keputusan adalah sifat yang akan muncul pada anak jika pembelajaran wirausaha ditumbuhkan sejak dini. Sifat tersebut merupakan modal bagi keberhasilan hidup anak saat dewasa kelak.

Pendidikan di sekolah menjadi tanggung jawab guru. Jadi pada dasarnya yang berpengaruh terhadap perkembangan anak yaitu proses pendidikan di sekolah sebagai bekal untuk diterapkan dalam kehidupan di lingkungan masyarakat. Seorang guru dalam proses pendidikan juga dapat memberikan motivasi dan dorongan kepada anak dalam menumbuhkan minatnya. Oleh karena itu menumbuhkan 
pembelajaran wirausaha (entrepreneurship) harus ditanamkan oleh pendidik di sekolah ketika anak-anak masih dalam usia dini.

Kewirausahaan ternyata lebih kepada menggerakkan perubahan mental. Seperti pengenalan terhadap diri sendiri (selfawareness), kreatif, mampu berfikir kritis, mampu memecahkan permasalahan (problem solving), dapat berkomunikasi, mampu membawa diri di berbagai lingkungan, menghargai waktu, empati, mau berbagi dengan orang lain, mampu mengatasi stres, bisa mengendalikan emosi dan mampu membuat keputusan.

\section{Penerapan Pembelajaran Kewirausahaan Anak Usia Dini}

Pembelajaran kewirausahaan pada anak usia dini dapat diimplementasikan secara terpadu dengan kegiatan-kegiatan pendidikan di sekolah. Pelaksanaan pendidikan kewirausahaan dilakukan oleh kepala sekolah, guru, peserta didik secara bersama-sama sebagai suatu komunitas pendidikan. Pendidikan kewirausahaan diterapkan ke dalam kurikulum tersembunyi (hidden curriculum) dengan cara mengidentifikasi jenis-jenis kegiatan di sekolah yang dapat merealisasikan pendidikan kewirausahaan dalam kehidupan sehari-hari, seperti :

1. Pendidikan Kewirausahaan Terintegrasi Dalam Seluruh Kegiatan belajar melalui bermain. Yang dimaksud dengan pendidikan kewirausahaan terintegrasi di dalam proses pembelajaran adalah penginternalisasian nilai-nilai kewirausahaan ke dalam pembelajaran sehingga hasilnya diperolehnya kesadaran akan pentingnya nilai-nilai, terbentuknya karakter wirausaha dan pembiasaan nilai-nilai kewirausahaan ke dalam tingkah laku peserta didik sehari-hari melalui proses pembelajaran baik yang berlangsung di dalam maupun di luar kelas pada semua kegiatan belajar melalui bermain. Langkah pengintegrasian bisa dilakukan pada saat menyampaikan materi, melalui metode pembelajaran maupun melalui sistem penilaian. Nilai-nilai pokok kewirausahaan yang diintegrasikan ke semua kegiatan belajar melalui bermain pada langkah awal ada 6 (enam) nilai pokok yaitu: mandiri, kreatif, pengambil resiko, kepemimpinan, orientasi pada tindakan dan kerja keras.

2. Pengintegrasian nilai-nilai kewirausahaan dalam silabus dan RPP dapat dilakukan melalui langkahlangkah berikut: 1) Mengkaji SK dan KD untuk menentukan apakah nilai-nilai kewirausahaan sudah tercakup di dalamnya. 2) Mencantumkan nilai-nilai kewirausahaan yang sudah tercantum di dalam SK dan KD kedalam silabus. 3) Mengembangkan langkah pembelajaran peserta didik aktif yang memungkinkan peserta didik memiliki kesempatan melakukan integrasi nilai dan menunjukkannya dalam perilaku. 4) Memasukan langkah pembelajaran aktif yang terintegrasi nilai-nilai kewirausahaan kedalam RPP.

Kegiatan pembelajaran kewirausahaan dapat dilakukan pendidik dengan cara: 1) Menyediakan sejumlah kegiatan yang dapat diikuti oleh peserta didik sesuai dengan kebutuhan, potensi, bakat, dan minat mereka; 2) Menyelenggarakan kegiatan yang memberikan kesempatan peserta didik mengekspresikan diri secara bebas melalui kegiatan mandiri atau kelompok.

Metode pembelajaran yang digunakan adalah memasukkan kegiatan kewirausahaan secara kreatif dalam materi pembelajaran yang akan diberikan guru, dengan cara seperti : 1) Anak-anak diajak untuk bertanam tanaman muda, anak menanam, merawat sampai memanen sendiri, dan pada saatnya anak akan menjual hasil tanamannya kepada orang tua yang datang, kemudian uang hasil penjualan di tabung untuk menjadi uang kas kelas. Dan setiap anak mempunyai catatan akan jumlah uang yang dihasilkannya; 2) Mengunjungi tempat kegiatan kewirausahaan sambil berkarya wisata seperti peternakan sapi atau tempat pembuatan makanan khas daerah dan lain-lain. Anak-anak akan melihat setiap proses dari kegiatan; 3) Anak dapat juga diajak mengunjungi tempat perbelanjaan seperti pasar tradisional dan swalayan. Terlebih dahulu anak-anak dibekali guru antara lain uang secukupnya dan catatan apa yang akan dibeli. Anak akan belajar menghitung, membayar, bahkan menerima kembaliannya. Peran guru dalam kegiatan ini sebagai pengawas dan motivator.

Perencanaan dan pelaksanaan pendidikan kewirausahaan dapat dilakukan melalui pengintegrasian kedalam kegiatan sehari-hari sekolah misalnya kegiatan 'family day' (dimana anak menjual hasil karyanya) dan orangtua terlibat langsung dalam kegiatan wirausaha (entrepreneur). Dalam membuat program "Family Day" dimana ayah dan bunda terlibat dalam kegiatan sekolah diantaranya menampilkan pentas, hasil karya yang di buat anak serta berbagai makanan yang telah anak coba pada program masak- 
memasak, diharapkan orangtua bertanya proses pembuatannya sehingga titik berat kegiatan ini adalah bagaimana anak bisa menjelaskan pada orang dewasa karya yang telah mereka buat, dan juga mengajarkan pembelajaran kewirausahaan bahwa apa yang telah mereka buat dapat menghasilkan karya dan uang, dalam hal ini orang tua juga diminta untuk membeli hasil karya anak dan seluruh hasil penjualan ditabung sebagai kas kelas.

Selanjutnya orangtua dapat mengajarkan anak untuk mampu mengelola uang dengan baik. Terangkan pada anak, dari mana uang yang dipakai untuk membiayai rumah tangga. Jelaskan bahwa untuk mendapatkan uang tersebut, orangtua harus bekerja keras. Uang hanya boleh dipakai untuk kebutuhan yang benar-benar perlu. Dengan demikian anak akan menjauhi sikap konsumtif. Dalam mengajarkan anak mengelola uang, latihan yang perlu diajarkan bukan hanya cara membelanjakan, tapi ketika akan berbelanja, catat terlebih dahulu kebutuhan yang akan dibeli. Orangtua harus konsisten untuk tidak berbelanja di luar catatan belanja. Biasakan anak untuk menabung dan mengatur uangnya dengan baik. Dengan demikian uang yang mereka dapat tak segera dihabiskan untuk hal-hal yang tak perlu.

Cara yang dipakai oleh David Owen, seorang penulis buku di Amerika Serikat, agaknya layak ditiru. Owen mengisahkan tentang bagaimana ia mampu mendorong anak-anaknya menjadi gemar menabung dan penuh perhitungan dalam membelanjakan uang. Ia membuat "Bank Ayah", khusus untuk anakanaknya. Prinsip yang dikembangkan dalam "Bank Ayah" adalah pemberian tanggungjawab dan kontrol keuangan secara penuh pada anak sebagai pengelola uang mereka sendiri. Uang anak adalah milik anak, bukan milik orangtua. Bahkan anak juga bebas mencari pendapatan di luar jatah uang saku yang telah mereka dapatkan.

Dalam hal ini "Bank Ayah" berperan dalam melakukan kontrol secara tidak langsung, yaitu dengan mengembangkan prinsip-prinsip perbankan seperti bonus yang dapat menarik minat anak untuk menambah saldo tabungan, juga saldo minimal, yang dapat membatasi jumlah pengambilan uang agar tidak terkuras habis. Dengan ini anak akan benar-benar bertanggungjawab dan berhati-hati dalam membelanjakan uangnya. "Bank Ayah" ala David Owen ini tidak cuma menjadi daya tarik anak untuk menabung. Lebih dari itu "Bank Ayah" dikelola sebagai sarana pembelajaran dari praktik ekonomi kepada anak dengan bahasa yang sederhana. Dengan sedikit improvisasi, Owen mengubah "Bank Ayah" ini menjadi media latihan berinvestasi pada anak-anaknya.

\section{KESIMPULAN}

Ketika lahir manusia itu masih kosong tidak punya pikiran apapun, tidak bisa mengartikan apa-apa, kemudian orang tua yang mengajarkan, menunjukkan sesuatu kepada anak, baik berupa kata-kata maupun perbuatan. Seiring berjalannya waktu semakin banyak pelajaran yang diberikan dan semua itu masuk dalam memori anak.

Dalam membentuk jiwa entrepreneur maka apa yang harus dilakukan orang tua kepada anaknya sejak kecil sampai masa remaja dan dewasa, yaitu ajarkan dan beri contoh, ingatkan setiap saat, dorong dan dukung tentang bagaimana memanfaatkan peluang yang ada, peluang waktu, peluang barang, peluang jasa, peluang uang, peluang keterampilan, peluang kepandaian, peluang pertemanan, peluang kerjasama, peluang kepercayaan.

Sekolah merupakan tempat anak mendapatkan pengetahuan, pengalaman dari ucapan, perilaku dan sikap para guru. Sekolah memiliki pengaruh yang cukup besar dalam proses pembelajaran, maka anakanak dengan mudah meniru apa yang ada disekolah. Semua itu memperkaya pembentukan pola pikir baik positif maupun negatif. Oleh karena itu dalam rangka menumbuhkan pola pikir entrepreneur sebaiknya dimulai dari tingkat pendidikan terendah sedini mungkin. Karena membentuk entrepreneur dan entrepreneurship tidak bisa dilaksanakan dengan instan. Pepatah mengatakan bila membuat parang maka harus ditempa ketika besi masih lunak. Anak-anak diibaratkan besi yang masih lunak dan mudah dibentuk tanpa patah.

Jadi sejak dini pembelajaran kewirausahaan baik untuk ditanamkan. Inti dari kewirausahaan adalah bagaimana menanamkan cara untuk berusaha, memecahkan permasalahan dan bertanggung jawab penuh atas apa yang anak lakukan. Selain anak harus kreatif maka gurunya juga mesti kreatif dan inovatif serta bersedia melakukan pembimbingan pada anak kearah penguasaan karakter wirausahawan. 


\section{DAFTAR PUSTAKA}

Alizamar, A., Ifdil, I., Fadli, R. P., Erwinda, L., Zola, N., Churnia, E., ... \& Rangka, I. B. (2018). The Effectiveness of Hypnotherapy in Reducing Stress Levels. Addictive Disorders \& Their Treatment.

Gunawan Ardiyanto. (2009). Jadi Pengusaha Siapa Takut. Kompas Gramedia: Jakarta

Ibrahim Rifky. (2010). Terapi Berpikir Positif. Zaman :Jakarta.

Ibrahim Hamd Al-Qu'ayyid. (2008). 10 Kebiasaan Manusia Sukses Tanpa Batas. Maghfiroh Pustaka : Jakarta.

Depdiknas. (2010). Peraturan Menteri Pendidikan Nasional Republik Indonesia Nomor 58 Tahun 2009 tentang Standar Pendidikan Anak Usia Dini (PAUD). Depdiknas : Jakarta

Departemen Pendidikan Nasional dan ILO. (2005). Mari Belajar Bisnis. Depdiknas: Jakarta

Desyafmi, H., Firman, F., \& Ifdil, I. (2016). Peningkatan Motivasi Siswa dalam Menyelesaikan Tugas Melalui Layanan Informasi. Konselor, 3(1), 35-41.

Fitri, E., Zola, N., \& Ifdil, I. (2018). Profil Kepercayaan Diri Remaja serta Faktor-Faktor yang Mempengaruhi. JPPI (Jurnal Penelitian Pendidikan Indonesia), 4(1), 1-5.

Kosn, N. N. A. M. (2016). Implementasi Permainan Tradisional Indonesia di Taman Kanak-Kanak Kota Padang. Pedagogi: Jurnal Ilmu Pendidikan, 15(1), 85-93.

Munandar, Utami. (2009). Pengembangan Kreativitas Anak Berbakat. Jakarta: Rineka Cipta.

Nurhafizah. (2010). Urgensi Pendidikan Karakter dalam Pendidikan Anak Usia Dini. Conference Proceeding Seminar Nasional Aktualisasi Pendidikan Karakter Bangsa. Vol. 1, 283 - 293

Nurhafizah. (2011). Keluarga sebagai Basis Pengembangan Nilai dalam Rangka Pembentukan Karakter Anak sejak Usia Dini. Sukabina Press: Padang

Nurhafizah. (2011). Mengembangkan Karakter Anak Usia Dini melalui Seni Tari. Conference Karakter sebagai Saripati Tumbuh Kembang Anak Usia Dini, Vol. 1, 324-336

Nurhafizah. (2012). Relationship Between the Intencity Parents Guidance to Early Math in Kindergarten. IPG Kampus Ilmu Khas: Kuala Lumpur.

Nurhafizah. (2014). Penanaman Perilaku disiplin Pada Anak Sejak Usia Dini. PG-PAUD FIP UNP: Padang

Nurhafizah N. (2015). Pengembangan Kreativitas Menggambar Anak Usia Dini dengan Penerapan Metode Ekspresi Bebas. Proceeding Seminar Nasional Peran Pendidikan Anak Usia Dini (PAUD) Dalam Meningkatkan Mutu Pendidikan di Indonesia, Vol. 1, 17-24.

Padang, P. F. U. N. Strategi Pengembangan Kemampuan Sains Anak Taman Kanak-Kanak di Koto Tangah Padang.

Reski, N., Taufik, T., \& Ifdil, I. (2017). Konsep diri dan kedisiplinan belajar siswa. Jurnal EDUCATIO: Jurnal Pendidikan Indonesia, 3(2), 85-91.

Rianto Nugroho. (2009). Entrepreneur Ciputra. Kompas Gramedia :Jakarta.

Syafitri, Nining. Faktor-faktor yang Mempengaruhi Belajar dan Pembelajaran. http://www ningningocha.wordpress.com.21 November 2011

Sujiono, Yuliani Nurani. (2009). Konsep Dasar Pendidikan Anak Usia Dini. Jakarta: PT Macanan Jaya Cemerlang.

Zola, N., Fadli, R. P., \& Ifdil, I. (2018). Chromotherapy to reducing stress. 